\section{International Archives of \\ Allergy \\ Immunology}

\section{Hammer \\ R. Linke \\ F. Wagner \\ M. Diefenbeck}

Institute of Surgical Research, Klinikum Grosshadern, Ludwig-

Maximilian University, Munich, Germany

Int Arch Allergy Immunol 1998;116:5-21

\title{
Organs from Animals for Man
}

\begin{abstract}
In the following review some of the problems of xenotransplantation shall be discussed, based on the few experimental data available so far and on reports in the literature describing investigations which may be of importance for xenotransplantation. The impact of gravity on the upright posture of man versus almost all other mammals, the dysfunction between enzymes and hormones in different species and the lack of interactions between interleukins, cytokines and vasoactive substances will be taken into consideration. The question must be asked whether different levels of carrier molecules or serum proteins play a role in the physiological network. Even though the development of transgenic animals or other imaginative manipulations may lead to the acceptance of any type of xenografted organ, it has to be established for how long the products of the xenografts are able to act in the multifactorial orchestra. We are far from understanding xenogeneic molecular mechanisms involved in toxicity, necrosis and apoptosis or even reperfusion injury and ischemia in addition to the immediate mechanisms of the hyperacute xenogeneic rejection. Here, cell adhesion, blood clotting and vasomotion collide and bring micro- and macrocirculation to a standstill. All types of xenogeneic immunological mechanisms studied so far were found to have a more serious impact than those seen in allogeneic transplantation. In addition we are now only beginning to understand that so-called immunological parameters in allogeneic mechanisms act also in a true physiological manner in the xenogeneic situation. These molecular mechanisms occur behind the curtain of hyperacute, accelerated, acute or chronic xenograft rejection of which only some folds have been lifted to allow glimpses of part of the total scene. Other obstacles are likely to arise when long-term survival is achieved. These obstacles include retroviral infections, transfer of prions and severe side effects of the massive immunosuppression which will be needed. Moral, ethical and religious concerns are under debate and the species-specific production of proteins of the foreign donor species developed for clinical use suddenly appears to be a greater problem than anticipated.
\end{abstract}

Species-specific physiology

\section{Key Words}

Xenotransplantation

Evolution .....................

\section{Introduction}

Could organs from certain mammals one day make up for the current shortage of organs available for transplantation?

The grafting of living organs, tissues and/or cells from animals onto humans, whether genetically modified or not, is called xenotransplantation [1]. Such transfer of animal organs to humans appears on the horizon as a last resort to meet the severe shortage of transplants of human origin for patients suffering from end-stage disease.

The constant progress in organ procurement and immunosuppression has not only prolonged survival and quality of life of transplanted patients but has also increased the de-

\begin{tabular}{lc}
\hline KARGER & 1998 S. Karger AG, Basel \\
E-Mail karger $(\mathrm{gkarger} . \mathrm{ch}$ & $1018-2438 / 98 / 1161-0005 \$ 15.00 / 0$ \\
$\begin{array}{l}\text { Fax }+41613061234 \\
\text { www.karger.com }\end{array}$ & $\begin{array}{l}\text { This article is also accessible online at: } \\
\text { http://BioMedNet.com/karger }\end{array}$
\end{tabular}
Correspondence to: Prof. Dr. C. Hammer
Institute of Surgical Research, Klinikum Grosshadern
Ludwig-Maximilian University, Marchioninistrasse 15
D-83166 München (Germany)

Tel. +4989709544 02, Fax +498970958897 
mand for grafts. Thus the waiting lists and waiting time have extended world wide.

Between December 1987 and 1991 the number of patients on waiting lists in the US has increased from 13,153 to 23,500: an increase of more than $75 \%$ [2]. In the same period, the number of organs available for transplantation increased only by $15 \%$. The ratios are similar in Europe where the numbers of patients waiting for an organ have increased by $32 \%$ between 1990 and 1994, from 11,021 to 14,585, whereas donations dropped by $4 \%$ from 1,615 to 1,544 organs [3]. However this slight increase or stagnation in the numbers of transplantations is, not due to organ donation but to the better use of multiorgan procurement.

All common parenchymal organs are in short supply but the demand for different grafts varies considerably. By far the greatest number of patients are waiting for kidneys, followed by those requiring hearts, livers and lungs. For kidney patients, a long-term alternative help is available in the form of dialysis, for heart patients short-term support is possible with machines, but for those requiring a liver no artificial organ has been produced to date.

Xenogeneic organ transplantation now seems the most promising solution to tackle organ shortage. The slow progress made in this field from 1964 until 1994 has limited these expectations [4]. The rapid development in genetic engineering of animals, particularly of pigs, however, has since stimulated the interest of scientists in clinical xenotransplantation [5].

When a branch of research suddenly or finally prospers, the obvious advantages, researchers enthusiasm and overly optimistic publications mislead the public and the patients by either raising false hopes or creating unjustified fears. A survey of 1,004 healthy individuals in Germany revealed, that only $6 \%$ would prefer to receive an animal organ than a human organ while $32 \%$ preferred a cadaver graft and $36 \%$ would prefer to take an organ from a living related donor. These attitudes changed with age and severity of disease. Only $20 \%$ of healthy youngsters said they would accept a pig heart if necessary, but among those aged over 50 years, $50 \%$ said they could imagine living with a porcine heart. Of those patients on the waiting list $80 \%$ would accept a pig heart provided the quality of life would be as good as with an allograft. These figures are similar in Europe, Australia and the US.

Although several experimental immunological approaches and a few immunosuppressive drugs have succeeded in prolonging xenograft survival by preventing some reaction cascades which finally evoke graft destruction, most anatomical, physiological and biochemical interactions between different animal species have yet to be understood and encountered before xenotransplantation can be a viable proposition. These interactions depend on species-specific characteristics of molecules and their receptors and regulators. Precise research on these obstacles to transplantation has not even started [6].

\section{Suitability of Source Animal Species}

It was not foreseen by nature that a peculiar species would one day have the idea to use organs and tissues from another species for its own advantage. Variation and adaptation to the environment were the aim of evolution. Natural selection over 3 billion years has consequently resulted in about 2-5 million species inhabiting the earth today. Of approximately 4,100 mammalian species, one quarter are small rodents unsuitable for clinical xenotransplantation. Only a few species, mainly those domesticated by man, would be appropriate as organ sources on the basis of size and anatomical characteristics [7].

Survival time of xenografts has been shown to be inversely proportional to the phylogenetic distance between the two species involved. Transplants between individuals of one zoological family, for example primates, are rejected by cellular mechanisms in an acute-type reaction. The survival times are of clinical interest, and conventional immunosuppression is effective. Grafts between members of two zoological families of one order are rejected in a mixed humoral/cellular fashion with survival times of less than a few days [8]. In this moderately related system, immunosuppression is of limited value. Organs exchanged between creatures of two zoological orders like the pig and man are destroyed within minutes by a hyperacute humoral process. However, this general pattern comprises many inconsistencies [9-11].

The success of xenotransplantation appears to depend on certain characteristics, such as age and type of organ. Fetal grafts seem to have advantages over mature organs [12-14]. Parenchymal whole organs are more susceptible to hyperacte rejection (HAR) than single cells, and primary vascularized organs initiate rejection mechanisms different from those that underwent neovascularization [15]. Certain braditrophic tissues such as biovalves from the pig or kangaroo [16], already used clinically in large numbers, are better tolerated than other tissues such as bone and cartilage [17]. The location of grafting plays an important role too, as cells transplanted to sites such as the testes, brain or the anterior eye chamber occupy a privileged site and undergo a much less severe rejection $[18,19]$. 


\section{Primates for Xenotransplantation}

Old World monkeys are the closest zoological relatives of man. Organs from chimpanzees and baboons have been used already for clinical xenotransplantation. The survival times achieved with rather simple immunosuppression indicated that these grafts would be suitable already today [20-22].

However, several concerns exist about using primate organs on a large scale.

Endangered nonhuman primates are protected. Their reproduction for transplantation is regarded as unethical. Raising germfree chimpanzees would be very expensive and time consuming. Due to the short life of a chimpanzee, the comparatively long maturation time and the years of intensive care required for their babies, it would take many decades to produce the number of organs needed today. Recommendations have been made for using such primates only for children.

The evolutionary relationship carries the risk of transferring similarly related pathogens to man [23]. Many human diseases have been seen in primates. Infections from man to primates are well known from primates kept in captivity or zoos. Baboons are related to man in similar way as for example cats to dogs, according to various zoological markers. The rejection of baboon organs by man is of the 'moderate' type and many physiological parameters seen in baboons are quite different from those of man. The production of specific pathogen-free baboons would be as costly and as time-consuming as with chimpanzees, and the risk of transmitting infectious diseases is similar. The organ size, even that of a male baboon, is still much less than that of an adult human being and is therefore not sufficient in most cases [24]. The idea of trapping wild baboons for xenotransplantation has to be discarded because of the contamination of these animals with all types of infectious material. Furthermore the selective elimination of adult males from their tribes would destroy the social life of a baboon gang and lead to their extinction within a short time.

\section{Pigs for Xenotransplantation}

The remaining alternative is to use an animal similar in size to man, readily available, without carrying the same danger of infectious diseases as primates. The routine supply of porcine organs for transplantation is regarded as ethically acceptable. The domestic pig was found to possess all advantages except immunological and physiological compatibility. Porcine and human organs have approximately
Table 1. Comparison of cardiac output (\%) between the pig and man

\begin{tabular}{lrr}
\hline Organ & Pig & Man \\
\hline Heart & 4.5 & 4.3 \\
Brain & 5.1 & 12.9 \\
Gastrointestinal tract & 18.4 & 20.0 \\
Liver & 26.3 & 21.3 \\
Kidneys & 17.0 & 18.9 \\
Skin & 5.0 & 8.6 \\
& &
\end{tabular}

Almost identical values are found in human and porcine organs in terms of organ perfusion. The human brain shows a significantly higher demand than the pig brain.

the same size and a similar efficiency [25]. The cardiac output is almost identical to that of man (table 1). Due to these characteristics, and zoological advantages, and immunological as well as physiological disadvantages, the following review will focus mainly on the transplantation of two widely divergent discordant species, the pig and man.

\section{Evolutionary Hurdles to Xenotransplantation}

The fundamental problems of xenotransplantation are the tempo and mode of evolution. It is the zoological diversity and histoincompatibility which are reflected by the speed of phylogeny and which again are reflected in the severity of rejection [26]. The limited success is due to the fact that xenotransplantation requires a much deeper knowledge of biology than allografting and many more aspects of evolution also have to be kept in mind. To approximate the success of xenotransplantation one has to distinguish between zoologically closely related species (concordant) such as apes and man or mouse and rat, and widely divergent individuals such as the pig and man or the pig and the $\operatorname{dog}[27]$.

Concordant and discordant xenografts have different fates. Concordant grafts are rejected almost like allografts, predominantly by cellular components in an acute fashion. Here most parameters involved are either identical or at least similar enough to be recognized in an allogenic or semiallogenic mode. The survival times approach those of an allograft. The rejection can be controlled by conservative immunosuppression [28, 29].

In transplants between two zoological families of one order, for example from the cat to the dog, other humoral 
Table 2. Rates of albumin evolution (index of dissimilarity)

\begin{tabular}{lrll}
\hline Primate species & ID & Canine species & ID \\
\hline Man & 1.00 & Dog & 1.00 \\
Gorilla & 1.09 & Coyote & 1.06 \\
Chimpanzee & 1.14 & Wolf & 1.16 \\
Orangutan & 1.22 & Jackal & 1.18 \\
Baboon & 2.23 & Fox & 1.20 \\
Capuchin monkey & 5.00 & & \\
Tupai & 11.00 & & \\
Cattle & 32.00 & & \\
Pig & $>35.00$ & & \\
\hline
\end{tabular}

Albumin is the major carrier molecule for hormones, enzymes and other essential molecules. Its evolutionary rate is exceptionally regular in different species. Albumin is therefore called the 'evolutionary clock' or 'index of dissimilarity' (ID).

mechanisms take over and lead to an accelerated rejection with maximum function times of less than a day [30]. In discordant combinations, like pig to dog or pig to man, organs are destroyed by purely humoral mechanisms, triggered by preformed natural antibodies and complement, followed by extremely complex if not chaotic nonimmunological processes. This HAR destroys a xenograft within minutes. A true function of the graft can rarely be measured.

Numerous elements of evolution have an impact on the feasibility of xenotransplantation. Genetics, anatomy and physiology all separately relate to the evolutionary development of species and thus to xenotransplantation. The rate of evolution and zoological disparity between species over a given period of time are, however, unpredictable and peculiar to each species. Isolation or the drift of continents has changed the environmental niches of species and has forced accidental or spontaneous mutations as shown by Old World monkeys and New World monkeys [11] guinea pigs and rats, pekkaries and domestic pigs which all reject xenografts in a discordant fashion, despite belonging to the same orders, i.e. primates, rodents or pigs, species combinations in which normally a concordant rejection would be expected.

Molecular evolution on the other hand can develop with a remarkable regularity. The amino acid sequence of albumin changes to a similar degree over a given period of time in different groups of animals such as primates and canines [31]. The greater the structural resemblance between the albumins, the closer the species are related. This difference has been expressed as the 'index of dissimilarity (ID)' or 'evolutionary clock' and can be used as a key parameter for xenogeneic histocompatibility (table 2) [32]. Serum albumin represents the most common carrier molecule of steroid hormones, cholesterol and bilirubin and for example maintains blood osmolarity. Yet, despite these important functions, it is fully dispensable [33]. Individuals totally lacking serum albumin have been identified in several species (humans, dogs, and rats) and there appears to be no impairment of life.

The zoological relationship between donor and recipient is a multifaceted concept, with anatomy and physiology perhaps being more important variables to consider.

\section{Anatomical Differences}

The most obvious differences between man and mammals are the upright posture of man and the usually horizontal bearing of potential donor species such as pigs. Domestication has shown that appropriately sized donors could be produced relatively quickly. Their genetic skeleton, however, would not change as rapidly as its size. The original shape, structure and texture, as well as the basic mechanical and functional characteristics of organs would still exist [34]. Anatomical differences may impede successful surgical techniques. For example, differences in texture may give rise to suturing problems. Organs incompatible in size are prone to be either compressed in the new smaller recipient or enlarged by edema or hemorrhage as demonstrated in clinical experiments in which small baboon livers were transplanted into large human recipients [24]. Rhythmic breathing movements equalize inferior and superior tissue pressure in the organ in situ, facilitating macro- and microcirculation. This system has to be simulated in experimental set-ups [35].

The human upright posture is exceptional in the animal kingdom. Gravity could influence the suitability and success of transplants from animals of horizontal bearing into man. A comparison of heart valves originating from either the upright kangaroo or the horizontal pig transplanted into sheep demonstrated that the effective orifice of the kangaroo aortic valve is $17 \%$ larger than that of a pig valve of the same diameter. Thus, the stroke volume was higher and the resulting transvalvular pressure gradient was lower, reducing the demand on the host heart muscle. The muscular protuberance of the transplanted porcine valve is deprived of direct blood supply causing it to calcify and shrink more quickly than the kangaroo valve [16].

Blood circulation is influenced by posture. In the human lung, West [36] described three distinguishable zones. The lower third of the lung undergoes a larger change in volume 
during both inhalation and exhalation, and has a smaller resting volume than the apex. The different pressures measured in each zone are related to upright posture and variously affect the capillaries. The pressure of the blood vessels is more pulsatile in upright than in horizontal lungs. Together with species-specific differences in resistance at the blood-gas barrier, different hemoglobins and varying viscosity, gas transport could be disturbed if the lungs or heart from a horizontal animal were transplanted into an upright recipient.

Multiple pulmonary veins and their numerous modifications found, for example, in the pig need a surgical approach totally different from those of humans.

The transplantation of baboon livers to humans has also resulted in unsatisfactory technical outcomes [37].

\section{Physiological Characteristics}

If one day xenografts are tolerated for a long time, it is not known whether physiological mechanisms of the organs and their new hosts will be compatible. Almost no data exist which would allow an accurate prediction of the physiological function of xenografts in man. The short survival times achieved have not enabled assessments to be made about metabolic compatibility between species. The function of multicellular organs and organisms depends on the ability of cells to communicate with each other, which requires a controlled basic metabolism found in all mammals. Therefore the principal metabolic characteristics, such as $\mathrm{pH}$, osmolarity, organ blood flow, and cardiac output per unit may have little impact on the results of xenotransplantation [38].

It is still unknown how many specific physiological mechanisms might be incompatible until an organ dysfunctions in the new environment. A chain is as strong as its weakest link. For example, for the transport of many molecules, and due to their variable solubility, species-specific carrier molecules are needed. They have to be secreted by a 'compatible' liver. Due to the extremely fast evolutionary rate of these 'modern' molecules, large differences exist between species. Such variations or lack of matching molecules from an incompatible donor could for example make the action of hormones impossible in the discordant xenogenic situation. Selected examples of physiological and biochemical variations between species will be addressed.

\section{Hormones and Growth Factors in Different Species}

Peptide hormone molecules are impotent or irrelevant without the means to reach their target cells and there to evoke a response. This delivery system can only function when effector molecules bind to the specific receptor, when transport, storage and secretion of hormones are tuned in a species-specific fashion and feedback components and inhibitors are linked to this process. The metabolism of these hormones is regulated by releasing factors, activating the prehormone to the stable form that must fit to its binding site(s) required for the species-specific cellular functions or release of products or expression of molecules on the call surface. Other complex chains of intermediate molecules and enzymes are integrated to achieve satisfactory results. Just one disparate factor could disrupt such a sequence [39, 40].

Binding of the human growth hormone to its receptor is required for regulation of normal growth of human organs especially bone, cartilage and muscles, including the heart muscles, also regulates protein and fat metabolism [40]. The human growth hormone occurs naturally in serum. Its structure is surprisingly similar to the topography and structure of the porcine growth hormone. This could imply molecular recognition between porcine receptors and human ligands [41]. This raises the question of whether transplanted xenogeneic fetal or adult animal organs would grow satisfactorily or, conversely, become giant organs under the influence of the human growth hormone. In other words, could porcine organs grow to the normal size found in a pig weighing up to $350 \mathrm{~kg}$ and if so over what period?

It is questionable whether monitoring circulating hormones is physiologically meaningful. It could reflect nothing but excess production from the xenogenic transplant site or the nonexistence of hormonal degrading mechanisms. It has been shown, however, that the porcine liver is able to metabolize porcine and human growth hormones to a similar degree.

In other species growth hormones have a different impact on different organs and cells. Experiments show that transgenic mice carrying bovine or human growth hormone genes develop into giant mice [42]. The human gene products are not recognized as foreign due to neonatal tolerance and no immunological reaction occurs. However, there is also no downregulation because the physiological speciesspecific inhibitors for human growth hormone do not exist in the mouse, thus leading to overproduction of a functional molecule which is associated with marked glomerular and tubular changes leading to decrease in life span [43].

Int Arch Allergy Immunol 1998;116:5-21 


\section{Classification of Xenogenic Rejection}

Function and survival time of xenografts as well as of allografts depends on the zoological relationship. In transplantation between members of one zoological species where different degrees of histocompatibility like auto-, iso- and allogeneity have been described, greater differences have been found in models involving different species. Transplantations between closely related species, usually belonging to one zoological family, result in a cellular acute rejection. Survival times are comparable to allografts. Most of these combinations are termed 'concordant'.

Grafts between moderately divergent species from two zoological families (e.g. cats and dogs) belonging to one zoological order develop an accelerated rejection of mixed type i.e. cellular and later humoral rejection mechanisms. Survival times are short and function is found to stop soon, if established at all. This type of rejection is not well investigated.

Widely divergent species are members of two zoological orders such as the pig and man. Perfusion times are ultra short. Function is limited if seen at all. The hyperacute xenogeneic rejection, by definition occurs within $48 \mathrm{~h}$, is dominated by humoral mechanisms involving xenoreactive antibodies, complement and other mediators [44]. Due to these characteristics, models of this zoological discrepancy are called 'discordant' [27].

At the moment, the main interest focuses on the mechanisms of hyperacute and accelerated xenogeneic rejection mechanisms. Acute or even chronic rejection is rarely investigated in xenografts because the recipient does not survive long enough for these to develop.

The pathological mechanism of chronic xenogeneic rejection is as poorly understood as in allotransplantation. Xenogeneic chronic rejection has been described only in primate models [45]. This reaction appears to occur earlier in xenotransplantation than in allotransplantation and to be even more difficult to control. Chronic rejection has not been observed so far in discordant animal combinations.

The pathogenesis of xenogenic rejections probably involves an interplay between immunogenic and nonimmunogenic factors. In contrast to allogenic rejection hyperacute rejection of discordant organs is heavily influenced by the effects of multiple nonimmunological mechanisms. This fulminant process becomes even more evident when warm ischemia or long total ischemia cannot be avoided. Both the nonimmunological mechanisms of HAR and mechanisms of reperfusion injury are similar and additive in their effect.The combined damage to the graft endotheli- um results in endothelial dysfunction, disturbance of microcirculation associated with leakage of humoral factors and cells into the parenchyma $[46,47]$.

Basically, preformed xenoreactive natural antibodies (XNA) directed against xenogenic glycoproteins and glycolipids, especially their alpha-1,3-galactosyl residues cause the classical pathway to activate the complement system (C). The alternative pathway does not involve antibody triggering. In both pathways, however, the central action is the formation of the $\mathrm{C} 3$ convertase, a protease which via the complement fractions $\mathrm{C} 3 \mathrm{~b}$ and $\mathrm{C} 5 \mathrm{~b}$ starts a cascade by which the opsonic membrane attack complex is formed. The consequences are the change of the vascular endothelium from an anti-coagulative stage to a procoagulative stage. The production of complement factors such as anaphylotoxins C3a and C5a, the loss anticoagulant factors such as heparan sulfate activating antithrombin III and superoxide dismutase, and the release of thrombomodulin induce the adhesion of leukocytes to the endothelium, and aggregation of platelets. Microvascular thrombosis and fibrin deposition together with vasoconstriction are the final stages of an MAR [49].

If HAR is postponed by either eliminating the XNA [5053] or by inactivating complement by various treatments then another process, i.e. accelerated rejection takes place [54]. If the latter occurs there is time enough to upregulate proinflammatory genes in the endothelial cells (EC) which produce procoagulative factors such as von Willebrand factor (vWF), platelet activating factor (PAF), tissue factor and P-selectin. Quantitative studies using intravital microscopy have shown that treatment with cobra venom factor, aspirin and PAF antagonists have no major impact on this phenomenon [55]. Depletion of XNA, including those specific for alpha-1,3-Gal, efficiently prevents HAR [56]. Leukocyte and thrombocyte adhesion was only marginally reduced even in extracorporeal perfusion experiments using human decay accelerating factor (h-DAF) transgenic porcine livers. Humoral rejection mechanisms, however, were significantly depresses and the function of organs significantly improved in h-DAF transgenic livers $[55,57]$.

\section{Transgenic Animals}

The most efficient approach to mitigate HAR is to express human complement regulator proteins such as h-DAF $[58,59]$ or membrane cofactor protein (MCP) on the surface of the xenogenic donor cells. A DNA construct incorporating the h-DAF gene was microinjected into the pronucleus of fertilized ova harvested from mature pregnant pigs. 
This h-DAF was expressed in different tissues and organs of the growing pigs. The extent of expression was, however, different in each of the first heterozygous animals and sometimes higher than in the equivalent human tissue. No genetic side effects were observed in these animals and their homozygous offspring $[6,60]$.

Transgenic pig hearts perfused with human blood in a working heart model [61] or transplanted heterotopically into cynomolgus monkeys showed significantly prolonged survival times up to 5.6 days [62] compared with normal transplanted pig hearts which survived for an average of $53 \mathrm{~min}$. EC activation and myocardial damage was significantly less than in nontransgenic hearts. Histologically, there was no sign of HAR in the transgenic hearts [63].

The delayed HAR could be further postponed by applying extreme immunosuppression with a combination of cyclosporin A, cyclophosphamide and steroids up to a maximum of 56 days. Orthotopically transplanted transgenic hearts kept recipient baboons alive for a maximum of 10 days. Most of the recipient animals had to be sacrificed due to severe immunological side effects although the transgenic hearts were still working properly $[64,65]$.

As long as such parenchymal organs work on a cell-tocell basis, not releasing products or spill over proteins, there is hope that they may overcome xenogenic destruction. As soon as the organs require an exogenous supply of speciesspecific hormones, cytokines or other regulator molecules their action might be severely hampered. In recent investigations it was shown that such proinflammatory cytokines were produced and released in patients after cardiac transplantation. The biological effects of the cytokines seemed to be mediated in part by secondary activation of the nitric oxide pathway and endothelin, leading to early endothelial dysfunction and cardiac disease or heart failure [66].

As soon as the endothelial barrier is destroyed by any mediator, complement or XNA, the same attacking mechanisms are now capable of lysing parenchymal targets. The strongly antigenic xenogenic proteins released into the circulation induce antibodies mainly of the IgG type, which behave even more specifically and aggressively than xenoreactive antibodies of the IgM class [67].

\section{Ischemia/Reperfusion in Xenografts}

Ischemia/reperfusion is important in allotransplantation and seems to have an even stronger impact on xenografts. Reperfusion of ischemic tissues initiates a complex series of reactions that paradoxically injure the tissues themselves. This is due to the production or release of inflammatory mediators comparable to those described for HAR. They also increase rolling and firm adhesion of leukocytes and their migration into the tissue. In the final step of reperfusion, the upregulation of adhesion molecules and production of cytokines occur again. Cytokines activate nuclear factor $x \beta$ in accelerated HAR and nonspecifically attract leukocytes to the injured organ [68].

In vitro experiments showed that prolongation of ischemia from 2 to $4 \mathrm{~h}$ markedly increased the extent of the injuries in hemoperfused porcine livers. It is known that long ischemia leads to the shedding not only of MHC class I and II molecules but also of vWF and others [69]. This would imply that xenografts cannot be transported or shipped over long distances but have to be transplanted immediately.

Most of the mechanisms described above were investigated in allogenic models. It has, however, to be considered that many of these reactions depend on species specific molecules, their species specific levels and possible or impossible interactions [70].

\section{Blood Viscosity}

Blood viscosity depends on the various blood components, including total protein and the size and number of erythrocytes and leukocytes. The number of RBC and WBC varies considerably between species. It has been demonstrated in perfusion experiments that the size of foreign cells can be critical and interfere mechanically with the microcirculation. The hematocrit represents $30 \%$ of the blood volume in pigs but $40 \%$ in man. Due to the higher viscosity of human blood reduced hemoperfusion of pig organs could be expected. This would be especially critical for coronary blood flow of the porcine heart or sinusoidal flow of the liver. In most experimental settings the hematocrit has been lowered to the normal porcine values or lower [71].

\section{Blood Groups}

The blood groups of most domestic animals have been studied. They resemble more closely the salivary blood groups as represented by the rhesus system than the $\mathrm{ABO}$ system of humans and primates [72]. From recent studies it seems that the human isohemagglutinins do not play any role in the rejection of pig organs [50,57].

Differences in potent factors of HAR such as interleukins, cytokines and adhesion molecules have been partially investigated [73]. Most of the knowledge of these factors 
results from allogeneic experience and has been extrapolated without proof to xenotransplantation. Some of the published data are described in more detail elsewhere $[73,74]$.

\section{Inducing Tolerance to Xenografts}

Regarding all the immunological and physiological obstacles, there seems to be only one solution, the induction of immunological tolerance. This would solve not only the problems of rejection but would also induce (neonatal) tolerance against all species-specific and otherwise antigenic products of the xenografts. Whether this will help to overcome the physiological incompatibilities cannot be foreseen.

Cellular response against xenografts follows the hyperacute and accelerated xenogenic rejection mechanisms which are mainly of the humoral type. This reaction is stronger than that encountered for allografts. Such reactions involve both $\mathrm{T}$ cells and additional cell populations as for example NK cells, monocytes and macrophages. It has been shown, that porcine MHC class II antigens are potent stimulators of direct $\mathrm{T}$ cell recognition [75]. It is therefore likely that CD4 cells also work in transgenic pigs. This must be assumed, because porcine vascular ECs express porcine leukocyte antigens as well as costimulatory molecules which may act across the species barrier [76]. These reactions need immunosuppression to a degree that will be considerably greater than that currently required to control allograft rejection [77]. It already becomes clear that this immunosuppressive treatment leads of live-threatening infections and complications unacceptable for a human patient [65]. Several groups are attempting to mitigate and even eliminate this cellular response by inducing xenogenic tolerance [78].

In systems of closely related species like the rat and mouse on the baboon and cynomolgus monkey, first successful bone marrow transplantations have been reported. The protocols involved nonmyeloablative irradiation and administration of anti-T-cell and anti-NK cell antibodies prior to administration to the xenogenic donor bone marrow [79]. In first attempts, this approach has been extended to discordant species such as pig and nonhuman primates. The additional treatment of absorption of anti-alph-1,2 Gal antibodies and immunosuppression with cyclosporin an deoxispergualin was needed. To achieve xeno-bone marrow engraftment, recombinant cytokines were administered.

Long-term suvival of these xenogenic bone marrow cells was observed, and normal pig kidneys transplanted to these chimeras resulted in a function time of up to 15 days [80-
82]. If this approach one day turns out to function over a longer period of time, the extreme immunosuppression applied today could be reduced to an amount bearable also by a human being.

\section{Xenogenic Liver Transplantation and Perfusion: Functional Capacity}

Xenogenic clinical liver transplantation from a chimpanzee to a 7-month-old child [83] and from baboon to two adult patients one in hepatic coma, and one with hepatitis B and HIV infection have been described [84]. The child died after $26 \mathrm{~h}$, the adult patients died after 26 and 72 days, respectively, from graft failure.

Hepatic xenotransplantation between pigs and primates or dogs and pigs all resulted in severe HAR [85]. Early publications regarded hemoperfusion as the critical parameter [86]. In the pig-to-dog experiments, severe destruction of the organ was seen after 5-10 min of perfusion. This typical HAR occurred despite both species possessing alpha-1,3 Gal epitopes. XNA directed against these epitopes have not been investigated, but should theoretically not exist in these species [87]. More recent experiments using sophisticated extracorporeal perfusion models show that active metabolism ceases as early as $30 \mathrm{~min}$ after the onset of perfusion. Dramatic and faster release of liver enzymes and intracellular electrolytes can be measured and indicate severe cell lysis [46]. Bile production, a reliable parameter for liver function, decreased significantly in the first $3 \mathrm{~h}$ [88]. Granulocytes and to a lesser degree platelets were retained in the grafts. Most mediators such as elastase, IL-1 $\beta$, IL-RA and interleukins were released in large quantities from human blood. Due to a lack of species-specific reagents, the products could not be detected [53].

Intravital microscopy, feasible only in livers of small animals (rats), has been used to prove that firm adhesion of leukocytes takes place in rat livers within minutes of perfusion with human blood. Most leukocytes roll and firmly adhere to the endothelium of portal veins. Thrombocytes aggregate to a similar degree $[55,57]$. Absorption of XNA and administration of CVF improved the production of bile, decreased resistance but did not reduce the adhesion of WBC (fig. 1, 2) [55].

Transgenic pig livers perfused with human blood showed improved function for a prolonged time but resulted in severe reduction of some of the measured parameters of liver function $[46,53]$.

The liver is the largest parenchymal organ that can be transplanted. It produces $95 \%$ of the circulating proteins in- 


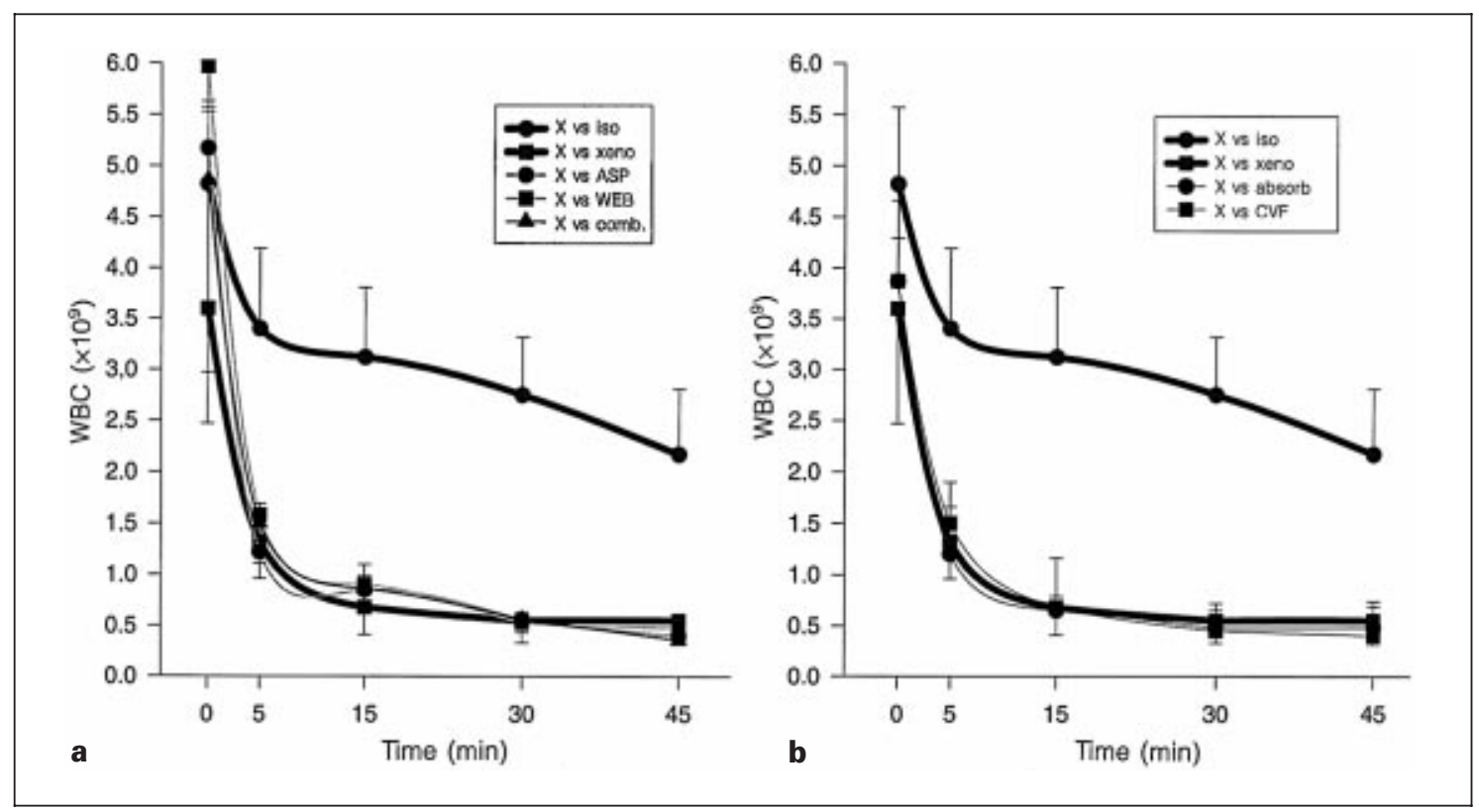

Fig. 1. Behavior of leukocytes during thrombocyte blockade by aspirin (Aspisol) and platelet activation factor inhibitor (WEB) (a) and immunomodulation using apheresis and cobra venom factor (CVF) (b). Measurements taken in an IVM set-up.

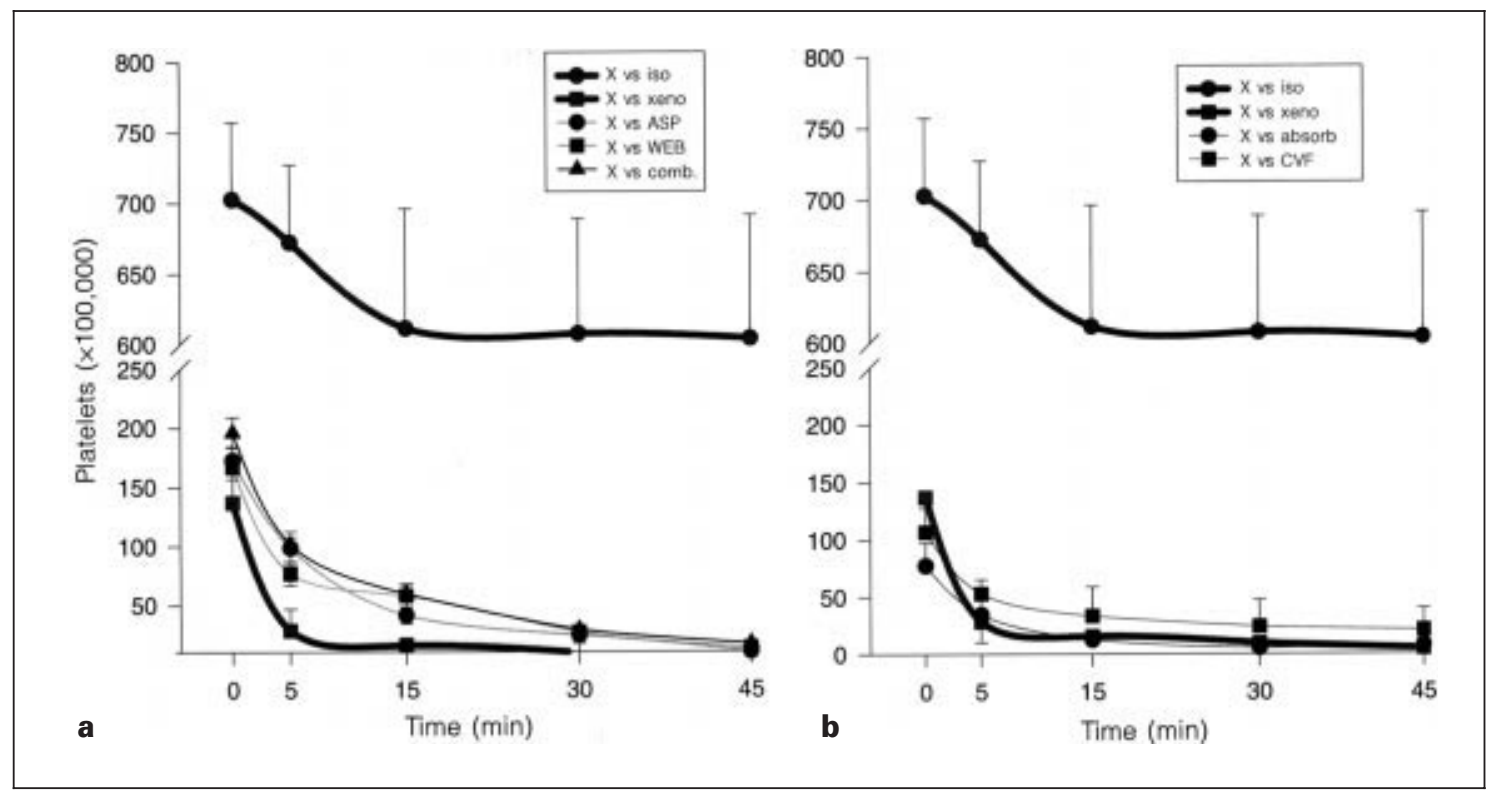

Fig. 2. Behavior of thrombocytes during thrombocyte blockade by aspirin (Aspisol) and platelet activation factor (WEB) (a) and immunomodulation using apheresis and cobra venom factor (CVF) (b). Measurements taken in an IVM set-up. 
Table 3. Differences in bile salts and their conjugates in some mammalian species

\begin{tabular}{lll}
\hline Species & Bile salt + derivates & Conjugate \\
\hline Primates & all three CHA & taurin/glycin \\
Pig & hyodesoxy CHA & taurin \\
Ungulates & chenodesoxy CHA & glycin \\
Carnivores & all three CHA & taurin \\
$\quad$ Brown bear & ursodesoxy CHA & glycin \\
$\quad$ Polar bear & chenodesoxy CHA & taurin \\
Rodents & CO-muricholic acid & taurin \\
$\quad$ Mouse & CHA/ $\alpha+\beta$ murichol acid & glycin \\
Rat/mouse & chenodesoxy CHA & glycin \\
Rabbit & desoxycholic acid & glycin \\
Marsupials & all three CHA & taurin \\
\hline
\end{tabular}

Bile salts and their conjugates show major differences even between rather closely related species like bears and rodents. $\mathrm{CHA}=$ Cholic acid.

cluding 2,500 different enzymes and is the source of $95 \%$ of the complement fractions, whether transplanted or not. ECs of the liver and Kupffer cells are potent producers of interleukins, interferons and numerous vasoactive substances. Almost nothing is known about the importance of ITO cells and other matrix cells in this xenogenic interaction. Most of the proteins produced are species specific and antigenic when released into a xenogenic circulation.

The liver also has the task of metabolizing hormones and growth factors [89] and absorbing bile salts. Bile salts and their carrier molecules are also species specific, sometimes even in closely related species (table 3 ), probably due to differences in nutrition. Human and porcine bile salts are remarkably similar [90].

Species differences in drug metabolism have been described [91] while elimination of, for example, ethanol by a pig liver was found to be comparable to that of man [92].

Synthesis of apolipoproteins takes place in the liver and the gut. Its purpose is the transport of many molecules, especially cholesterol, to the liver. Plasma cholesterol levels in pigs $(45 \mathrm{mg} / 100 \mathrm{ml})$ are significantly lower than in man $(200 \mathrm{mg} / 100 \mathrm{ml})$. This might be due to the transfer of cholesterol esters from high-density lipoproteins (HDL) to lowdensity lipoproteins (LDL). Pigs exhibit a significantly lower binding capacity of LDL than humans. This is thought to be due to the higher levels of apo-B receptor in pigs ( $950 \mu$ $\mathrm{mol} / \mathrm{l})$ than in man $(125 \mu \mathrm{mol} / \mathrm{l})$. It could be regarded as a beneficial effect of the porcine liver in lowering human cholesterol levels.

The degree of binding is different in various species, and LDLs have species-specific structures. The protein and gene sequences of LDH indicate a rather high evolutionary rate. The amino acid sequences of LDLs in mammals differ from 20 to $40 \%$ in mammals and man [93].

In contrast, the insulin of pigs and man differs only in one amino acid. Other animals show stronger species variations in insulin leading to antibody production in transplantations between divergent animal species [94]. Furthermore, the specific insulin binding levels and receptor affinity in pigs are comparable with those of human hepatocytes [95]. The physiology of pig insulin seems to be very similar to that of man.

Protein production from the pig liver would result in species-specific foreign molecules with high antigenicity [96]. The modification after degradation of such molecules adds to the antigenicity and results in different levels of branched-chained amino acids (BCA) and aromatic amino acids (AAA). A significant difference in the BCA/AAA ratio was found after hemoperfusion of a pig liver with human blood. However, there was no shift towards a pig profile of plasma amino acids, indicating a nonfunctional xenograft [97].

Summarizing these observations, it becomes clear that enzymes which are sometimes very different in their serum levels between man and pigs need careful control (fig. 3). If they do not build a coherent system in which they and their isoenzymes can interact in a species-specific way, the total effect of their activities can be total chaos. To what extent these innumerable mechanisms might upset the metabolism in a discordant species is unknown. Xenotransplantation of a porcine liver to man seems to have chances of success only in the distant future. Whether such organs should be used to bridge a waiting time needs very sophisticated investigations especially of the metabolic aspects.

\section{Xenogenic Kidney Transplantation and Function}

Kidneys eliminate soluble metabolic products, excessive ions and water from the body. Three functions are involved: glomerular filtration, tubular reabsorption and tubular secretion.

Tubular functions depend on hormonal regulations and receptors. The membranes involved consist of proteins and specific carriers and enzymes which transport low-molecular substances. Defects and species differences in sodiumdependent carriers for glucose, amino acids and phosphate could lead to isolated disorders of reabsorption.

The function of these brush border enzymes is to cleave filtered molecules such as hormonally active peptides and peptide hormones. As shown in figures 4 and 5, the electro- 
Fig. 3. Liver enzymes occur naturally in the serum. Their values vary considerably between pig and man. The question is, how many enzymatic discrepancies can exist and how long until the foreign metabolism is severely disturbed or interrupted.

Fig. 4. Sodium, potassium and chloride concentrations in the serum are overlapping in the pig and man. Calcium and phosphorus, however, show completely different values. Their urinary excretion is significantly higher in the pig than in man.

Fig. 5. While most renal parameters are similar between the pig and man, cholesterol and uric acid concentrations are significantly lower in the pig than in man.
Asparte aminotransferase

Alanine aminotransferase

Creatinine phosphokinase

$\gamma$-Glutamyltransferase

Alkine phosphatase

Amylase

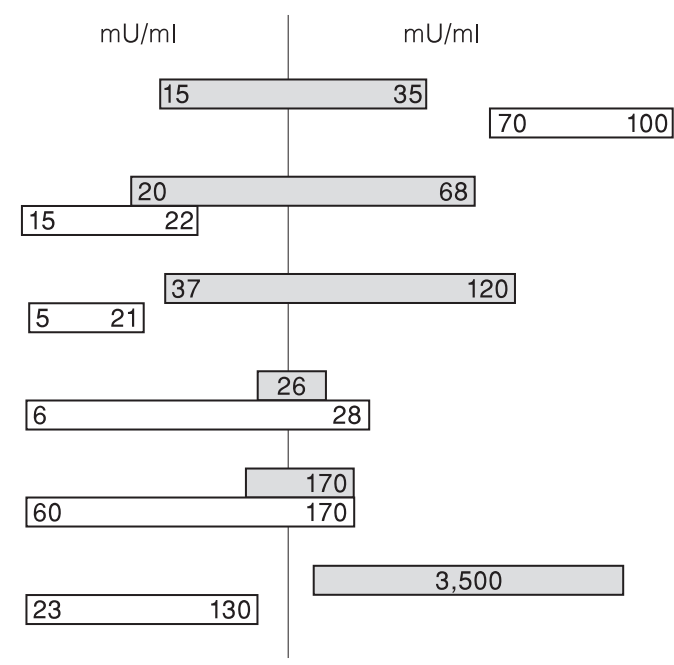

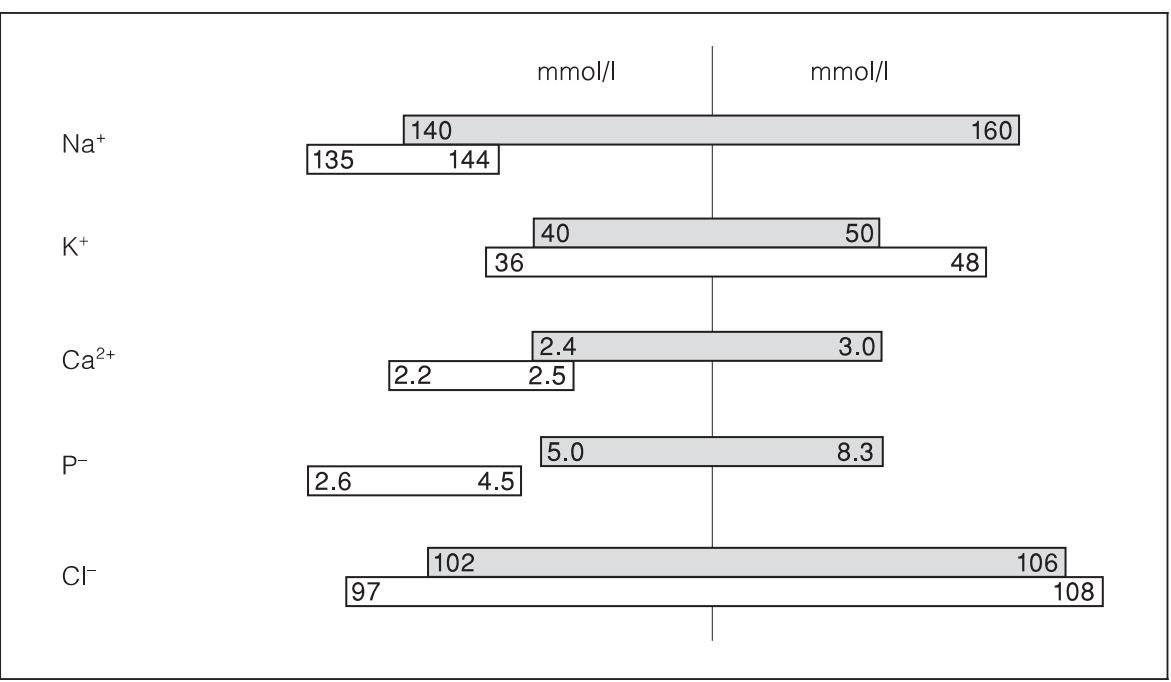

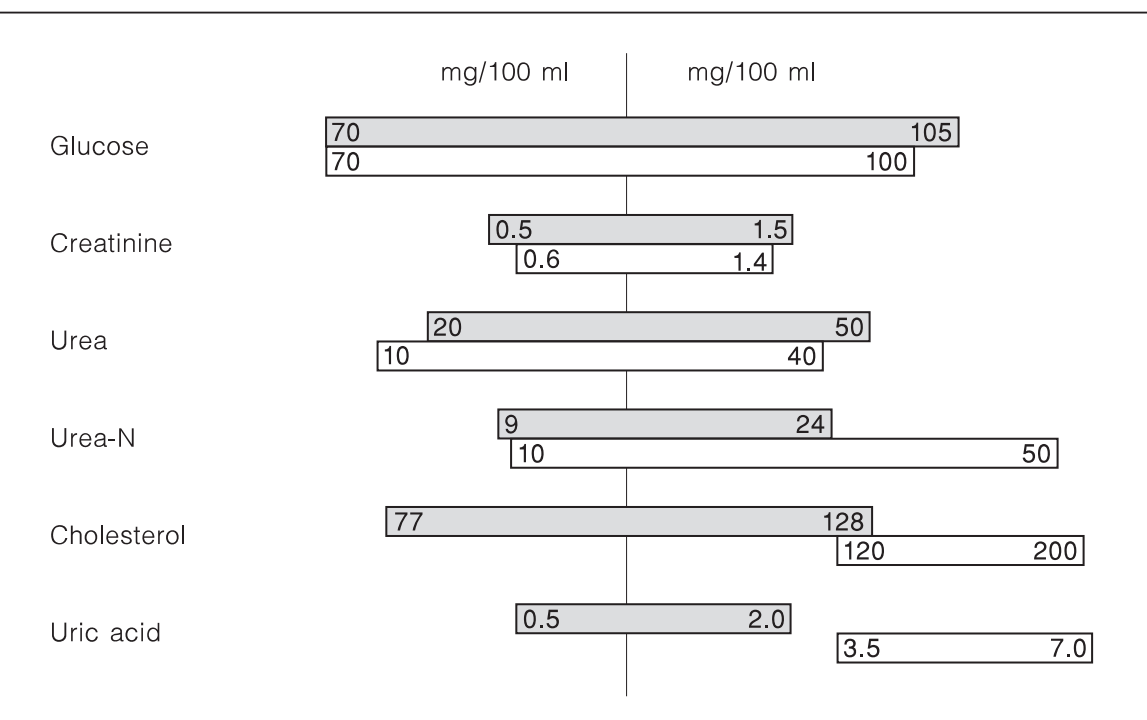

Organs from Animals for Man 
lyte values of pig and man are surprisingly different. Only potassium and chloride levels are reported to be identical between man and pigs. All of the other electrolytes, especially calcium, are totally different between the two species. Other parameters such as levels of creatinine, urea and urea $\mathrm{N}$ could be similar, although uric acid is much higher in humans.

Xenogenic kidney transplantation from chimpanzees to man yielded the best results ever achieved in this field [98]. Baboon kidneys were significantly less successful [99]. Porcine kidneys connected to the human circulation ended without exception in HAR [100].

In perfusion experiments using primates as recipients, pig kidneys were rejected hyperacutely [101]. Pig to rabbit [102] and pig to dog [103], despite compatible 1,3 Gal residues and no anti-Gal antibodies, all ended in even faster HAR. Pig kidneys hemoperfused with human blood ended in HAR within less than $2 \mathrm{~h}$ [51]. Isovolemic hemodilution in which both XNA and $\mathrm{C}$ were reduced to unmeasurable levels significantly prolonged the subsequent perfusion time. However, kidney function was lost after less than 30 min [103]. Rabbit kidneys transplanted to newborn piglets before feeding, thus without XNA, also were condemned to HAR [104]. The best results reported for pig kidneys (SVT 28 days, $\mathrm{n}=1$ ) were obtained after transplantation to a baboon which had been pretreated with immunosuppression unacceptable for man (splenectomy plus plasmapheresis plus immunosuppression plus infusion of blood group antigens) [50]. After apheresis of anti 1,3 Gal XNA and severe immunosuppression, pig kidneys survived for 15 days) in a baboon [82]. Transgenic pig kidneys transplanted to cynomolgus monkeys have functioned for up to 72 days with normal creatinine values and only minor changes in serum electrolytes [107], indicating that differences in renal metabolism and hormone regulation could be tolerated for a prolonged period of time [105].

Anemia related to differences in species-specific erythropoietin (EPO) was found in these long-surviving animals. Species-specific EPO given to these monkeys was able to prevent this side effect. Recombinant EPO from various species indicates cross-reactivity of EPO with the emergence of an autoimmune reaction due to the presence of $\operatorname{IgG}$ antibodies cross-reacting with the endogenous EPO. In other words, an immune reaction against the porcine EPO produced in the xenogeneic kidney could lead to a cross-reaction of XNA with the autologous EPO [106]. This observation may affect the outcome of kidney xenotransplantation in man.

Another problem seems to be the action of adhesion molecules, for example following perfusion with human blood, as shown on porcine ECs from kidneys [107], ICAM-1, VCAM-1 and LFA-3 of pigs are not recognized by monoclonal antibodies directed against the human molecules. LFA1 and CD44 integrins mediate cross-species interactions. The blocking of inhibition of these adhesion molecules reduces adhesion of lymphocytes by a third, suggesting additional non-integrin-dependent adhesive interactions [108].

\section{Xenogenic Heart Transplantation}

The first, but unsuccessful, clinical heart transplantation was performed in 1964 by Hardy [109], 4 years before the first successful allogenic heart was transplanted by Barnard [110]. The small chimpanzee heart was not able to provide sufficient cardiac output for the human patient and stopped functioning after $24 \mathrm{~h}$. Other xenografts from sheep and pig [111] were hyperacutely rejected. The transplantation of a baboon heart to a neonate by Bailey [22] caused sensation. The child survived for 20 days, the longest survival time ever achieved with a xenogeneic heart. The last trial by Czepanicki [112], who transplanted a pig heart into a patient with Marfan syndrome ended after $24 \mathrm{~h}$.

In the same time, numerous extracorporeal models and a working heart device were developed in order to investigate HAR and the immunological reactions also in transgenic pig hearts [113]. The transplantation of h-DAF transgenic pig hearts to the abdominal aorta of cynomolgus monkeys resulted in a beating time of up to 62 days, mean 42 days [65]. Orthotopic transplantation of h-DAF transgenic hearts to juvenile baboons ended after a maximal time of 10 days, when the animals had to be sacrificed due to infections as a result of extremely high immunosuppression. The typical rejection mechanisms are described in detail and do not differ significantly from those of other transgenic organs [114].

The heart is regarded as a simple muscular pump with low immunogenicity. This is only true in terms of the phylogenetically stable myosin and myoglobin, which are both relatively similar in most mammals. However, the heart produces large amounts of vasoactive prostaglandins and endothelin. It depends on species-specific interleukins and its ECs produce large amounts of IL-6 and TNF. Other inflammatory mediators and procoagulants such as bradykinin, ADP and PAF together with angiotensin are involved in the HAR. Release of CK, LDH and ASAT during xenoperfusion indicates reperfusion injury of the early phase of activated endothelium [6].

After braking the endothelial barrier, XNA will get in contact with cardiomyocytes. There is, however, evidence, 
that sera containing XNA disturb the function of viable cardiomyocytes. Spontaneously beating cardiomyocytes with cell-to-cell contact forming a syncytium in the form of a monolayer beat synchronously. Addition of XNA to the medium led to temporary cessation of beating and long-lasting desynchronization although the cells were viable. Removal of XNA prevented these effects. Inactivation of complement had no impact on cell function. XNA severely altered the electrophysiological properties. The depolarization and reduced excitability could not be overcome by pacing [115]. These findings could explain the lack of prompt xenograft function as seen in ex vivo models and xenografts.

This in vitro reaction could explain the coincidence of induced IgG class antiporcine antibodies in monkeys receiving h-DAF transgenic pig hearts and the immediate function loss. Even extreme immunosuppression was not sufficient to inhibit the production of such antiporcine antibodies.

In experiments in which fox hearts were transplanted heterotopically to dogs under marginal immunosuppression (SVT 14 days), $50 \%$ of the following allografts were rejected hyperacutely and 33\% in an accelerated fashion. This phenomenon could be attributed to the production of crossreacting antibodies directed against fox MHC antigens cross-reacting with dog MHC antigens [116]. Bridging with organs from widely divergent species and in rodent models did not result in such types of reactions.

The sensitivity of porcine hearts to human growth factors and hormones could be a serious problem. Heart weights of primates and pigs vary considerably during life. h-DAF transgenic hearts when transplanted into slow-growing monkeys increased at a species-specific speed. In the clinical situation, this would lead to cardiac oversize with congestion of the other thoracic organs as seen in mice transgenic for human growth hormone [42].

\section{Xenozoonosis}

Xenotransplantation may carry the risk of transmission of infectious diseases from the source animal to the human recipient. Pathogens which are common among humans and other animals are mostly known and measures are available to prevent the spread of bacteria, fungi and protozoa. The risk of them being transferred increases with the closeness of the zoological relationship between the species. The transmission of pathogens from primates to man therefore is more likely than from pig to man. This is one reason why primates should not be used as source animals [117].
Wild baboons, for example, are known to carry diseases like tuberculosis, malaria, yellow fever but also a variety of herpes type viruses such as SA 8, simian type and herpes papio [118]. The Rous sarcoma virus, Epstein-Barr C-type virus were isolated and retroviruses such as STLV-1, the foamy virus and endogenous retrovirus and known to occur in baboons. Most of them have been proven to contaminate human cultured cells or cell lines. Others like hepatitis A and B are highly species specific and unable to cross the species barrier $[119,120]$.

Pigs carry several pathogens that eventually could harm human beings. They contain viruses like porcine influenza, parainfluenza virus and others, which are able to infect man, but during the long time of domestication of the pigs and close contact with farmers no disease has been found that endangered the human race. Recently, two endogenous retroviruses were identified in porcine cultured cells which are able to contaminate human cell lines [121,122].

No patient who so far has received a xenograft developed a specific animal disease. Humans like farmers, butchers or veterinarians living in close contact with pets or domestic animals have not been found to develop zoonosis more often than the rest of the population. People who, for religious reasons, have no contact with pigs suffer from the same pathogens carried by pigs as other people. Large amounts of animal products like porcine insulin, growth hormones and bovine albumin have been injected to immunosuppressed patients without inducing zoonoses.

Transplant recipients are immunocompromised due to their primary disease and this together with the severe immunosuppression needed after an eventual xenotransplant, increases the risk of infection. Breaking the physical tissue barrier between animals and man, by immune suppression of the human recipient, and genetic modification of the animal could each make the transfer of viruses more likely. Even if the pathogens could be controlled by the patient's immune system in the autologous tissue, they could reactivate in the xenograft and destroy the organ. Retroviruses when multiplying use the membrane of the host cell as their own capsule and therefore are antigenic to a new discordant host. Preformed antibodies destroy the new invader which, for example, carries the 1,3 Gal epitopes or the foreign species-specific complement regulator protein, which is now impotent. In transgenic animals not expressing the 1,3 Gal or carrying the h-DAF on their surface, these rejection mechanisms may be paralyzed as on a xenograft. The individual risk of such a retrovirus infection by a xenograft recipient is more likely than in a normal individual.

Particular concern hase been raised over latent viruses that are unknown or difficult to detect or endogenous virus- 
es which are not pathogenic for the original host but when transplanted with the graft into the patient with low immunological resistance create a new disease. Incomplete pig retroviruses could recombine with the human counterpart and create a new hybrid form. This hybrid could be a potentially dangerous virus which could rapidly mutate and change its characteristics. Such animal pathogens with an unknown latent period and incubation time are difficult to identify. They could be passed on from the patient to the next relative or the staff and to the public at large. A similar pattern of behavior was seen with rotaviruses from the cat and dog which do not share a high degree of homology but in contrast to all other rotavirus strains are capable of contaminating human beings $[123,124]$.

Xenotransplantation has raised many questions for the virologist at a time when much interest is already focused on AIDS, and the Hong-Kong chicken flue and other new viral diseases.

The guidelines and principles of caution developed by several working groups and transplantation societies should prevent an easy transfer of pathogens by xenotransplantation. One of the most important ways of avoiding potential dangers of disease transmission is the production of animals free from known infectious material. Methods and practices to create pathogen-free pigs and even gnotobiotic animals have been developed for other purposes before [125].

\section{Ethical Aspects}

For the last 5 years, information of the public about xenotransplantation by the media has not always been adequate. Similar to gene technology and gene therapy or animal cloning, scientific achievements have been published in a rather sensationalist fashion, than as a tremendous progress. Journalists do not properly investigate but stir hysteria. Patents and the financial interest of the pharmaceutical industry have an inhibitory impact on the progress of xenotransplantation. The interest and fate of the patients often seem to be lost under these aspects [126].

Many guidelines and memoranda already exist. Transplantation societies [127], the monotheistic churches [128] and ethical committees [129] have published issues about their views on xenotransplantation. In fact, xenotransplantation would have the chance, probably as the first advanced method in medical history, to be ethically guided and clinically applied in a controlled fashion.

\section{References}

1 Committee of ministers to member states on xenotransplantation, 3rd Conference of European Health Ministers, Paris, Nov 1987.

2 Evans RW, Orians C, Ascher N: The potential supply of organ donors. JAMA 1992;267:139245.

3 Cohen B, D’Amaro J, De Meester J, Persijn GG: Changing patterns in organ transplantation in Eurotransplant, 1990-1996. Transplant Int 1997; 10:1-6.

4 Auchincloss H: Xenogeneic transplantation. Transplantation 1988;46:1-20.

5 Cozzi E, White DJG: The generation of transgenic pigs as potential organ donors for humans. Nat Med 1995;1:964-966.

6 Hammer C: Nature's obstacles in xenotransplantation Transplant Rev 1994;8:174-184.

7 Hammer C: Evolutionary considerations in xenotransplantation; in Hardy M (ed): Xenograft 25. Amsterdam, Elsevier, 1989, p 115.

8 Chaline J, Cardoso D, Houssin D: Organ xenografting between rodents: An evolutionary perspective. Transplant Int 1994;7:216-221.

9 Sugimoto K, Shelby J, Corry RJ: The effect of cyclosporin on caridac xenograft survival. Transplantation 1985;39:218-219.
10 Hammer C, Chaussy C, Welter H, Wembacher J, Höbel G, Brendel W: Exceptionally long survival time in xenogeneic organ transplantation. Transplant Proc 1981;13:881-884.

11 Collins BH, Cotterell AH, McCurry KR, et al: Hyperacute rejection of cardiac xenografts performed between primate species (abstract). Am Soc Transplant Surg 21st Annu Meeting, Chicago, 1995, p 117

12 Hammelmann W, Gray D, Cairns T, Ozasa T, Ferguson D, Cahill A, Welsh K, Morris P: Immediate destruction of xenogeneic islets in a primate model. Transplantation 1994;58:11091114.

13 Mandel TE, Koulmanda M: Fetal pig pancreas xenografts in non-obese diabetic mice treated with continuous anti-CD4 monoclonal antibody. Transplant Proc 1991;23:583-584.

14 Tsui K, Kanai N, Kise Y, Takebe K, Shimura T, Nakajima S, Kato H: Can fetal xeno whole-organ grafts escape from hyperacute rejection in experimental discordant combinations as compared with adult xenografts? Transplant Proc 1997;29:3022-3023.

15 Menger M, Hammersen F, Messmer K: The microvasculature of free pancreatic islet grafts; in Messmer K, Stein M (eds): Pathways in Applied Immunology. Berlin, Springer, 1991, pp 109-112.
16 Weinhold C, Weingartner J, Hammer C: In vivo investigation of kangaroo aortic valve xenoprosthesis: An experimental animal model; in Bodnar E, Yacoub M (eds): Biologic and Bioprosthetic Valves. New York, Yorke Med, 1986, pp 669-683.

17 Stone K, Walgenbach A, Abrams JT, Nelson J, Gillett N, Galili U: Porcine and bovine cartilage transplants in cynomolgus monkey. Transplantation 1997;63:640-645.

18 Ricordi C, Lacy PE: Renal subcapsular xenotransplantation of purified porcine islets. Transplantation 1987;44:721-723.

19 Bobzien B, Yasunami Y, Majercik M, Lacy P, Davie J: Intratesticular transplantation of xenogeneic islet grafts (rat to mouse). Diabetes 1983;33:213-215.

20 Reemstma K, McKracken K, Schlegel BH: Renal heterotransplantation in man. Ann Surg 1964;160:384-410.

21 Starzl T, Marchioro TL, Peters G: Renal heterotransplantation from baboon to man: Experience with 6 cases. Transplantation 1964;2:752776.

22 Bailey LL, Nehlsen-Canarella SL, Conception W: Baboon to human cardiac xenotransplantation in a neonate. JAMA 1985;254:3321-3329. 
23 Allan JS: Xenotransplantation at a cross roads: Prevention versus progress. Nat Med 1995;2: 18-21.

24 Starzl TE, Fung J, Tzakis A, Todo S, Demetris AJ, Marino IR, Doyle H, Zeevi A, Warty V, Michaels M, Kusne S, Rudert WA, Trucco M: Baboon to human liver transplantation. Lancet 1993;341:65-71.

25 Kirkman RL: Of swine and man: Organ physiology in different species; in Hardy M (ed): Xenograft 25. Amsterdam, Elsevier Sciences, 1989, pp 125-133.

26 Hammer C, Suckfüll M, Saumweber D: Evolutionary and immunological aspects of xenotransplantation. Transplant Proc 1992;24:23972400.

27 Calne R: Organ transplantation between widely disparate species. Transplant Proc 1970;2:550556.

28 Hammer C, Saumweber D, Krombach F: Xenotransplantation in canines; in Hardy M (ed): Xenograft 25. Amsterdam, Elsevier Sciences, 1989, pp 67-77.

29 Sanchez J, Michler RE, Rose EA, Cooper DKC: Experimental xenotransplantation between closely related primate species; in Cooper D (ed): Xenotransplantation. Berlin, Springer, 1993, pp 365-376.

30 Hammer C: Possible role of antibodies in xenogeneic rejection. Ann Cardiac Surg 1993;6: 172-179.

31 Sarich VM, Wilson AC: Rates of albumin evolution in primates. Proc Natl Acad Sci USA 1967;58:142-148.

32 Kimura M: Molecular evolutionary clock and neutral theory. J Mol Evol 1976;26:24-33.

33 Blauer G, Lavie E, Silfen J: Relative affinities of bilirubin for serum albumins from different species. Biochem Biophys Acta 1977;492: 64-71.

34 Herre W, Röhrs M: Haustiere zoologisch gesehen. Stuttgart, Fischer, 1973.

35 Neuhaus P, Blumhardt G: Improved methods of extracorporeal liver perfusion for temporary replacement of liver function; in Brunner G, Mito M (eds): Artificial Liver Support: Concepts, Methods, Results, ed 2. Berlin, Springer, 1992, p 225 .

36 West JB (ed): Respiratory Physiology, ed 3. Baltimore, Williams \& Wilkins, 1985.

37 Starzl TE: Liver allo- and xenotransplantation. Transplant Proc 1993;25:15-17.

38 Baumann G: Growth hormone binding proteins and various forms of growth hormones: Implications for measurement. Acta Paediatr Scand 1990;370:72-80

39 DeVos AM, Ultsch M, Kosiakoff AA: Human growth hormone and extracellular domain of its receptor. Science 1992;255:306-312.

40 Nicol CS, Mayer GL, Rusel SM: Stimulation of metabolism by growth hormone. Endocr Rev 1986;7:169.

41 Abdel-Meguid SS, Shieh H, Smith W, Dayinger H, Violand B, Bentle L: Three dimensional structure of genetically engineered variance of porcine growth hormone. Proc Natl Acad Sci USA 1987;84:6434-6467.
42 Wanke R, Hermanns W, Folger S, Wolf E, Brem $\mathrm{G}$ : Accelerated growth and visceral lesions in transgenic mice expressing foreign genes of the growth hormone family: An overview. Pediatr Nephrol 1991;5:513-521.

43 Brem G, Wanke R, Wolf E: Multiple consequences of human growth hormone expression in transgenic mice. Mol Biol Med 1989;6:531547.

44 Rosenberg JC, Hawkins E, Rector F: Mechanisms of immunological injury during antibody mediated hyperacute rejection of renal heterografts Transplantation 1971;11:151-158.

45 McManus RP, Kinney T, Komorowski R, Hunter J: Reversibility of cardiac xenograft rejection in primates. J Heart Lung Transplant 1991; 10:567-576.

46 Pöhlein C, Pascher A, Baumann P, Abendroth A, Jochum M, White D, Hammer C: Transgenic porcine livers reduce liberation of humoral mediators during xenoperfusion with human blood. Transplant Proc 1996;28:772-774.

47 Pascher A, Stangl M, Hammer C: Impact of immunoadsorption on complement activation, immunopathology, and hepatic perfusion during xenogeneic pig liver perfusion. Transplantation 1998; in press.

48 Hoopes CW, Platt J: Molecular strategies for clinical xenotransplantation in cardiothoracic surgery. Sem Thoracic Cardiovasc Surg 1996;8: 156-174.

49 Robson SC, Candinas D, Hancock W, Wrighton C, Winkler H, Bach FH: Role of endothelial cells in Transplantation. Int Arch Allergy Immunol 1995;106:305-322.

50 Alexandre G: Plasmapheresis and splenectomy in experimental renal xenotransplantation; in Hardy M (ed): Xenograft 25. Amsterdam, Elsevier Sciences, 1989, pp 259-267.

51 Tuso PJ, Cramer DV, Yasunaga C, Cosenza LA, Wu GD, Makowka L: Removal of natural xeno antibodies to vascular endothelium by perfusion of blood through pig kidneys and livers Transplantation 1993;55:1375-1378.

52 Cooper DKC, Human PA, Lexer G, Rose A, Rees J, Keraan M, De Toit E: Effects of cyclosporin and antibody absorption on pig cardiac xenograft survival in the baboon. J Heart Transplant 1988;7:238-246.

53 Pascher A, Poehlein C, Stangl M, Hoebel G, Thiery J, Mueller-Derlich J, Hammer C: Application of immunoapheresis for delaying hyper acute rejection during isolated xenogeneic pig liver perfusion. Transplantation 1997;63:867875.

54 Suchfüll M, Pieske O, Müdsam M, Hammer C: The contribution of endothelial cells to hyperacute rejection in xenogeneic perfused working hearts. Transplantation 1994;57:262-267.

55 Seehofer D, Baatz H, Thiery J, Hammer C: Quantitative analysis of the microcirculation of xenogeneic hemoperfused rat livers by intravital microscopy. Transplant Int 1996;9 (Suppl 1):97-99.
56 Lin S, Kooyman D, Daniels L, Dagget C, Parker W, Lawson J, Hoope C, Platt J: The role of natural anti-Gal alpha 1-3 Gal antibodies in hyperacute rejection of pig-to-baboon cardiac xenotransplants. Transplant Immunol 1997;5:212218.

57 Seehofer D, Baatz H, Thiery J, Müller-Höcker J, Müller-Derlich J, Hammer C: Fluorescence videomicroscopic assessment of xenogeneic microcirculation and impact of antibody removal by immunadsorption. Transplantation 1997; 63:460-465.

58 Dalmasso A, Vercelotti G, Platt J, Bach FH: Inhibition of complement-mediated endothelial cell cytotoxicity by decay accelerating factor. Transplantation 1991;52:530-533.

59 Rosengard A, Cary N, Langford G, Tucker A, Wallwork J, White D: Tissue expression of human complement inhibitor, decay-accelerating factor, in transgenic pigs. Transplantation 1995; 59:1325-1333.

60 White D, Langford G, Cozzi E, Young V: Protective effect of human DAF in transgenic pigs. Xeno 1995;3:48-51.

61 Schmöckel M, Nollert G, Shamohammadi M, Young V, Hammer C, Reichardt B: Prevention of hyperacute rejection by human decay accelerating factor in xenogeneic perfused working hearts. Transplantation 1996;62.729-734.

62 White D: HDAF transgenic pig organs: Are they concordant for transplantation? Xeno 1996;4:50-54.

63 Schmöckel M, Nollert G, Young V, White D, Hammer C, Reichart B: Transgenic human decay accelerating factor makes normal pigs function as a concordant species. J Heart Lung Transplant 1997; 16:758-764.

64 Cozzi E, Tucker A, Langford G, Chavez G, Wright L, Young V, White D: Characterisation of pigs transgenic for human decay accelerating factor. Transplantation 1997;64:1383-1392.

65 Schmöckel M, Wallwork J, White D: Cardiac xenograft organs from transgenic pigs; in Verrier ED, Franco KL (eds): Advance Therapy in Cardiac Surgery. New York, Kluver, 1998.

66 Wildhirt S, Weis M, Schulze C, Conrad N, Kornberg A, Rieder G, Enders G, Ueberfuhr P, Reichenspurner H, von Scheidt W, Reichart B: Impact of transcardiac cytokines, nitric oxid and endothelin on endothelium dependent coronary flow reserve after heart transplantation. Cardiovasc 1997;2:231-236.

67 Authenrieth A, Müller-Werdan U, Koidl B, Werdan K, Hammer C: Different action of xenoreactive natural and immune antibodies on functional cardiomyocytes. Transplant Proc 1996;28:576-577.

68 Bach F, Ferran C, Soares M, Wrighton C, Anrather $\mathrm{J}$, Winkler $\mathrm{H}$, Robson $\mathrm{S}$, Hancock W: Modification of vascular responses in xenotransplantation: Inflammation and apoptosis. Nat Med 1997;3:944-948.

69 Fox J: Shedding of adhesion receptors from the surface of activated platelets. Blood Coagul Fibrinolysis 1994;5:291-304.

70 Brown M, Zibari G, Granger D, McDonald J: Hepatic ischemia/reperfusion affects leukocyte rolling and velocity. Clin Transplant 1997;11: 511-515. 
71 Satoh S, Terajima H, Yagi T, Kanazawa A, Yamamoto M, Yamaoka Y: Humoral injury in porcine livers perfused with human whole blood. Transplantation 1997;64:1117-1123.

72 Schmid O, Buschmann HG: Blutgruppen bei Tieren. Stuttgart, Enke, 1985.

73 Hammer C, Dommer S, Allmeling A: Cross species interaction of xenogeneic interleukins. Transplant Proc 1996;28:858-859.

74 Millan M, Geczy C, Stuhlmeier KM, Googman D, Ferran C, Bach F: Human monocytes activate porcine endothelial cells, resulting in increased E-selectin, interleukin 8, monocyte chemotactic protein-1, and plasminogen activator inhibitor-type 1 expression. Transplantation 1997;63:421-429.

75 Brimele B, Thibault G, Nivet H, Gruel Y, Bardos P, Lebranchu Y: Human lymphocyte adhesion to porcine endothelial cells: Modulation by human TNF- $\alpha$ and involvement of VLA-4 and LFA-1. Transplant Immunol 1996;4:265-270.

76 Bone RC: Toward a theory regarding the pathogenesis of the systemic inflammatory response syndrome: What we do and do not know about cytokine regulation. Crit Care Med 1996;24: 163-171.

77 Matis L, Elliott E, Evans M, Mueller J, Rollins S, Rother R, Shanafelt M: The molecular basis of human anti-porcine cellular interactions. Xeno 1995;3:110-112.

78 Guinan E, Gribben J, Boussiotis V, Freeman G, Nadler L: Pivotal role of the B7:CD 28 pathway in transplantation tolerance sn tumor immunity. Blood 1995;54:3261-3282.

79 Sharabi Y, Aksentijevich T, Sundt T, Sachs D, Sykes M: Specific tolerance induction across a xenogeneic barrier: Production of mixed rat/ mouse lymphohematopoietic chimeras using non-lethal preparative regimen. J Exp Med 1990;172:195-202

80 Bartholomew A, Cosimi A, Sachs D, Bailin M, Boskovic S, Powelson J: A study of tolerance in a concordant xenograft model. Transplant Proc 1997;29:923-924.

81 Sablinski T, Gianello P, Bailin M, Bergen K, Emery D, Cosimi A, Sachs D: Pig to monkey bone marrow and kidney xenotransplantation. Surgery 1997;121:381-391.

82 Kozlowski T, Fuchimoto Y, Monroy M, Bailin M, Sablinski T, Ierino F, Sachs D: Apheresis and column absorption for specific removal of Gal-anti-1,3 Gal natural antibodies in a pig-tobaboon model. Transplant Proc 1997;29:961.

83 Giles G, Boehming HJ, Anemiya H, Halgrimson C, Starzl TE: Clinical heterotransplantation of the liver. Transplant Proc 1970;2:506-512.

84 Marino M, Doyle B, Nour B, Starzl TE: Baboon liver transplantation in humans: Clinical experience and principles learned; in Cooper DK, Kemp E, Platt JL, White D (eds): Xenotransplantation ed 2. Berlin, Springer 1997.

85 Calne R, Davis D, Pena J, Balner H, De Vries M, Westbroek D: Hepatic allografts and xenografts in primates. Lancet 1970;i:103-106.

86 Calne R, White H, Herberton B, Mallard P, Davis D, Samuel J: Pig-to-baboon liver xenografts. Lancet 1968;i:1176-1178.
87 Jerusalem C, Heyde M, Reinking J, Schmid W, Bilski R, Tjebbes F: Rejection phenomena in heterotopic liver homo- and heterografts. Transplant Proc 1971;3:554-557.

88 Pöhlein C, Pascher A, Storck M, Young V, König W, Abendroth D, Wick M, Thiery J, White D, Hammer C: The function of transgenic human DAF expressing porcine livers during hemoperfusion with human blood. Transplant Int 1996;9:392-396.

89 Cameron D, Burger H, Catt K, Gordon E, Watts J: Metabolic clearance of human growth hormone in patients with hepatic and renal failure, and in isolated perfused pig liver. Metabolism 1972;21:895-904.

90 Kwekkeboom J, Rpincen H, Voohuizen M, Meijer P, Kempen J: Comparison of taurocholate accumulation in hepatocytes of pig, rat and man. Biochem Biophys Res Commun 1989; 162:619-625.

91 Lesca P, Witkamp R, Maurel P, Galtier P: The pig as a model for studying $\mathrm{AH}$ receptor and other PAH-binding proteins in man. Biochem Biophys Res Commun 1994;200:475-481.

92 Keiding S, Johansen S, Midtboll I, Rabol A, Christiansen L: Ethanol elimination kinetics in human liver and pig liver in vivo. J Am Physiol Soc 1979;237:E316-324

93 Adham M, Ducerf C, Vernet M, Rigal D, Roche E, Bizollon T, Pouvet M: Changes in serum proteins during isolated pig liver perfusion. Transplant Proc 1997;29:3015.

94 Smith L: Species variations in the amino acid sequence of insulin. Am J Med 1966;40:662666.

95 Höllund E, Richelsen B, Pedersen O: Comparative studies of insulin binding to receptor from adipocytes, hepatocytes, monocytes and erythrocytes from the pig. Acta Endocr 1988; 118:59-67.

96 Richter M, Sargent A, Myers J, Rose B: Production of autoantibodies in rats immunized with homologous and heterologous liver. Fed Proc 1967;26:211-216.

97 Adham M, Vianey-Saban C, Ducerf C, Boyer S, Roche E, Pouyet M, Baulieux J: Plasma amino acid study during discordant liver xenoperfusion. Transplant Proc 1997;29:3016.

98 Reemtsma K, McCraken B, Schlegel J, Pearl M, DeWitt C, Smith P, Hewitt R, Flinner R, Creech O: Renal heterotransplantation in man. Ann Surg 1964;160:384-410

99 Starzl T, Marchioro T, Peters G, Kirkpatrick C, Wilson W, Porter K, Ogden D, Hitchkock C: Renal heterotransplantation from baboon to man. Experiences in 6 cases. Transplantation 1964;2:752.

100 Breimer M, Björck S, Svalander C, Bengtsson A, Rydberg L, Lie-Karlsen K, Attman P, Aurell M, Samuelson B: Extracorporeal ('ex-vivo') connection of pig kidneys to humans. Xenotransplantation 1996;3:328-339.

101 Platt J, Fischel R, Matas A, Reif S, Bolman R, Bach FH: Immunopathology of hyperacute xenograft rejection in a swine-to-primate model. Transplantation 1991;52:214-220.
102 Marini I, Ferla G, Celli S, Stieber A, Muttillo I, Maggiano N, Musiani P: Hyperacute rejection of renal discordant xenograft (pig-to-rabbit): Model assessment and rejection mechanism. Transplant Proc 1990;22:17071-17076.

103 Messier K, Hammer C, Land W, Fiedler L, Klövekorn W, Holper K, Lob G, Merzel D, Brendel W: Modification of hyperacute xenogeneic kidney rejection. Transplant Proc 1971; 3:542-546.

104 Johnston P, Lim S, Wang M, Wright L, White D: Hyperacute rejection of xenografts in the complete absence of antibody. Transplant Proc 1991;23:877-879.

105 Zaidi A, Friend P, Schmöckel M, Bhatti F, Waterworth P, Cozzi E, Dunning J, Wallwork J, White D: Hyperacute rejection is not consistent after pig to primate renal xenotransplantation (abstract 53). 4th Int Congress Xenotransplantation, Nantes 1997.

106 Wen D, Boissel J, Tracy T, Gruninger R, Mulcahy L, Goodman M, Bunn H: Erythropoetin structure-function relationships: High degree of sequence homology among mammals. Blood 1993;52:1507-1516.

107 Pleass H, Forsythe J, Proud G, Taylor R, Kirby $\mathrm{J}$ : Xenotransplantation: An examination of the adhesive interactions between human lymphocytes and porcine renal epithelial cells. Transplant Immunol 1994;2:225-230.

108 Storck M, Krombach F, Prestel R, Hammer C, Abendroth D: Role of adhesion molecules during ex-vivo kidney xenoperfusion. Transplant Proc 1997;29:3011-3012.

109 Hardy J, Kurrus F, Chavez C, Neely W, Webb W, Eraslan S, Turner M, Fabian L, Labecki J: Heart transplantation in man: Developmental studies and report of a case. JAMA 1964;188: 1132-1140.

110 Barnard C, Wolpowitz A, Losman J: Heterotopic cardiac transplantation with a xenograft for assistance of the left heart in cardiogenic shock after cardiopulmonary bypass. S Afr Med J 1977;52:1035-1038.

111 Cooley D, Hallman G, Bloodwell R, Nora J, Leachman R: Human heart transplantation: Experience with 12 cases. Am J Cardiol 1968; 22:804-810.

112 Czaplicki J, Blouska B, Religaz Z: The lack of hyperacute xenogeneic heart transplant rejection in a human. J Heart Lung. Transplant 1992;11:393-396.

113 Schmöckel M, Nollert G, Shahmohammadi M, Young V, Chavez G, Kaspar-König W, White D, Hammer C, Reichart B: Prevention of hyperacute rejection hy human decay accelerating factor in xenogeneic perfused working hearts. Transplantation 1996;62:729-734.

114 White D: H-DAF transgenic pig organs: Are they concordant for human transplantation? Xeno 1966;4:50-54.

115 Müller-Werdan U, Klein D, Zander M, Werdan $\mathrm{K}$, Hammer $\mathrm{C}$ : Beating neonatal rat cardiomyocytes as a model to study the role of xenoreactive natural antibodies in xenotransplantation. Transplantation 1994;58:1403-1409. 
116 Hammer C, Schütz A, Pratschke J, Breuer M, Engelhardt M, Brandl U, Saumweber D, Babic $\mathrm{R}$, Kemkes B, Reichart B: Bridging to transplant: Allogeneic heart transplantation after xenografting. J Heart Lung Transplant 1992;4: 182-188.

117 Chapman L, Folks T, Salomon D, Patterson A, Eggerman T, Noguchi P: Xenotransplantation and xenogeneic infections. $\mathrm{N}$ Engl J Med 1995;333;1498-1501.

118 Deinhardt F, Falk L, Wolfe L: Simian herpes viruses and neoplasia. Adv Cancer Res 1974; 19:167-205.

119 Deinhardt F: Hepatitis in primates. Adv Virus Res 1976;20:113-157.

120 Michaels M, Lanford R, Demetris A, Chavez D, Brasky K, Fung J, Starzl TE: Lack of susceptibility of baboons to infection with hepatitis B virus. Transplantation 1996;61:350-351.
121 Patience C, Tageuchi Y, Weiss R: Infection of human cells by an endogenous pig retrovirus. Nat Med 1997;3:282-286.

122 Le Tissier P, Stoye J, Takeuchi Y, Patience C, Weiss R: Two sets of human-tropic pig retrovirus. Nature 1997;389:681-682.

123 Nakagomi O, Nakagomi T: Interspecies transmission of rotaviruses studied from the perspective of genogroup. Microbiol Immunol 1993;37:337-348

124 Vonsover A, Shif I, Silberstein I, Rudich H, Nakagomi T, Nagakomi O: Identification of feline and canine-like rotaviruses isolated from humans restriction fragment length polymorphism assay. J Clin Microbiol 1993;31: 1783-1787.

125 Nuffield Council of Ethics, UK: Animal to human transplants. The Ethics of Xenotransplantation. London, Nuffield Council, 1996.
126 Hammer C: Comments on ethics in human xenotransplantation; in Cooper D (ed): Xenotransplantation. Berlin, Springer, 1997.

127 Sheil A: The Transplantation Society and xenotransplantation. Transplant Soc Bull 1997;6: 11-14.

128 Daar A: Ethics of xenotransplantation: Animal issues, consent, and likely transformation of transplant ethics. World J Surg 1997;21:975982.

129 Kennedy I: Xenotransplantation: Ethical acceptability. Transplant Proc 1997;29:27292730 .

\section{Announcement}

\section{IMGT NEWS - January 1998 \\ 'Protein Display - Three-Dimensional Representation - Sequences Analysis'}

IMGT, the international ImMunoGeneTics database, announces protein displays of human immunoglobulin and T cell receptor variable region, IMGT description of mutations and allele alignments (IMGT News - August 1997); the first three-dimensional representations of antibody and T cell receptor variable regions based on the IMGT unique numbering defined by Marie-Paule Lefranc (IMGT News - March 1997), and the IMGT/DNAPLOT tool for the analysis of human immunoglobulin and $\mathrm{T}$ cell receptor rearranged sequences and for the subgroup identification of the mouse IGHV sequences. IMGT is freely accessible at http://imgt.cnusc.fr:8104

Flash on IMGT:

$>25,000 \mathrm{Ig}$ and $\mathrm{TcR}$ sequences of 81 species

$>19,000$ sites connected since 1st of January 1996

$>3,500$ requests/week

IMGT initiator and coordinator:

Prof. Marie-Paule Lefranc

Laboratoire d'ImmunoGénétique Moléculaire, LIGM

UMR 5535 (CNRS - Université Montpellier II)

1919 route de Mende

F-34293 Montpellier Cedex 5 (France)

Tel. +334676136 34, Fax +33467040231

E-Mail lefranc @ligm.crbm.cnrs-mop.fr

IMGT references: Lefranc, Immunol Today 1997;18:509.

Lefranc et al., Nucleic Acids Res 1998;26:297-303. 